\title{
高速演算器の多重使用に関する一検討
}

\author{
正会員 佐々木 信 $之^{\dagger}$, 正会員 八 木 伸 行 $^{\dagger \dagger}$ \\ 正会員 福 井 一 夫 $^{\dagger+}$ 正会員 榎 並 和 雅 $^{\dagger \dagger}$
}

\section{A Study of Multiple Use for Fast Processors}

\author{
Nobuyuki Sasaki ${ }^{\dagger}$, Nobuyuki Yagi ${ }^{\dagger \dagger}$, Kazuo Fukui ${ }^{\dagger \dagger}$ \\ and Kazumasa Enami ${ }^{\dagger+}$
}

\begin{abstract}
This paper considers an algorithm that can realize the multiple use for plural fast processors For this purpose, the fast switching network which connects processors and variable delays is needed A DPS (Digital Signal Processor) chip model is assumed that includes plural multipliers, arithmetic logic units, variable delays, registers, and a cross point. The algorithm is studied for many examples and confirmed by software simulation The digital master control system for a broadcast station is studied as an example and the DSP chip model can be very successfully used for the TV master control system Each multıplier, alu, or variable delay is very efficiently assigned and the equipment could be made much smaller
\end{abstract}

\section{1. まえがき}

近年, 映像メディアの発展は著しく, 既存の放送局 はもとより, 放送衛星や通信衛星による放送や, 企業 におけるクローズドなユースによる利用，あるいはレ ンタルビデオに至るまで, 映像信号の豊富な情報量に 基づいた情報の授受はますます盛んになってきてい る. 一方, BS-3bにる 1 日 9 時間のハイビジョン 試験放送もすっかり軌道に乗り, NTSC, HDTVを 問わず, 安価で短期間の映像ソフトウェア制作の必要 性は日に日に高まっている。このような背景のもとで 筆者らは, 映像信号をプログラマブルに処理すること で, 自由度・拡張性が高く, 極めて短期間で新しい映
像処理が実現できるNTSC 版 Picot システム ${ }^{1)}$ 開 発したが，その延長として HDTVに対応できるシス テムを開発するに際し，HDTV，NTSCの両システ ムに効率良く対応できるための基本的な検討を行った ので，その結果を報告する。

本論文ではまず，HDTV，NTSCの各信号処理を ケーススタディし, 映像信号のプログラマブルな処理 の適用のために必要な機能を考察した。その結果を基 に, 複数の高速演算器とスイッチングネットワークを 持つプログラマブルな映像信号処理用プロセッサのモ デルを設定し，各種のケーススタディを行った。特に 同一デバイスでHDTV と NTSC の両方に対応する ことを想定し，その際，低速側の NTSC 信号の処理

キーワード：画像処理プロセッサ, ディジタル信号処理, 並列処理, HDTV

1992 年 7 月, テレビジョン学会年次大会で発表

1994 年 5 月 16 日受付, 1994 年 12 月 28 日最終受付

$\dagger$ 株式会社東芝 小向工場 映像情報技術部( $\mathbf{T} 210$ 川崎市小向東芝町 1, TEL 044-548-5114)

†† NHK 放送技術研究所 先端制作技術研究部 (于 157 東京都世田谷区砧 1-10-11, TEL 03-5494-2310)

$\dagger$ Komuka1 Works, Toshıba Corporation (1, Komuka1 Toshıba cho, Kawasakı shı, Kanagawa 210, Japan)

计 NHK Science and Technical Research Laboratories (1-10 11, Kinuta, Setazaya ku, Tokyo 157, Japan) 
において, 可変ディレイを調整することで高速演算器 の効率の良い多重使用を実現するアルゴリズムと, 複 数の低速信号処理を高速信号処理の回路構造のままで ディレイのみ変えて行う方式について詳細に論じた。

最近のディジタル信号処理デバイスには，9個の積 和演算器を 9 タップの 1 次元フィルタ構成と, $3 \times 3$ の 2 次元空間フィルタの構成を選択できるものや, ク ロック周波数を $1 / 2$ に落とすことでタップ数を 2 倍に するようなものもあるが，本研究のように任意の回路 構成に対して演算器を多重使用するような試みや製品 はいまだ存在ぜず，その有用性を確認できた。

\section{HDTV と NTSC の信号処理 ${ }^{12)}$}

筆者らは，NTSC版 Picot システムの開発に際し て, 放送機器 (主にNTSC のスタジオ用ディジタル機 器)の信号内容を分類した。その結果を表 1 に示す. ポイント処理とは画素毎の演算であり,さらに画素值 に依存して処理が変わるタイプ, フィールドシーケン スに依存するタイプなどに分かれる。 ただし画素値に 依存するタイプも, Look Up Table (LUT)を用いれ ば処理が可能である．時間軸処理はメモリーやディレ イにより異なる時間の画素の処理を行うもので, 画面 内では水平・垂直のディレイを使用し, 画面間ではフ イールドメモリーを介して Read/Write と演算を行 う. 波形発生処理は多角形を中心とした各種波形の発 生を行い, その他の処理は画面データやパラメータに 依存して頻繁に判断・分岐処理を行うものである. 特 に頻繁に条件分岐を要求される処理には*印をつけ た. 表 1 を見てもわかるように, 演算の形態はポイン 卜処理が主体であり, 演算内容は積和が主体であるが 非線形演算もあり, その他, アドレス演算などが含ま れる.また,これらの処理を行うための演算器の接続 形態は, コンボリューションのような一般的な形も含 めて様々であり, それらす心゙てに対応するためには, 演算器制御を高速に行えること, 演算器間接続切り換

表 1 放送用映像信号処理内容の分類 Classification of video signal processing for the broadcast use.

\begin{tabular}{l|l|l}
\hline \hline ポイント処理 & $\begin{array}{l}\text { データ依存型(LUT 使用) } \\
\text { データ独立型 } \\
\text { フィールド依存型 }\end{array}$ & $\begin{array}{l}\text { クロマキー } \\
\text { キーミックス, マトリクス } \\
\text { NTSCエンコーダ }\end{array}$ \\
\hline 時間軸処理 & $\begin{array}{l}\text { 画面内 } \\
\text { 画面間* }\end{array}$ & $\begin{array}{l}\text { エッジスーパー } \\
\text { 特殊効果 }\end{array}$ \\
\hline 波形発生処理* & & ワイプ \\
\hline その他処理* & & キーマット \\
\hline
\end{tabular}

えが高速に行えて，かつ接続の自由度が高いことが必 要である.

HDTVにおいても，NTSCに比べて処理速度が速 いこと以外は同様の分類になる。したがって, HDTV 用の信号処理プロセッサに必要な機能として は, NTSC用の信号処理プロセッサの機能におおむ ね準じることになるが, HDTV 用の信号処理プロセ ッサは当然, より低速である NTSC の信号も処理で きるので, HDTV 用の高速演算器を速度を落とさず にNTSC の低速信号に適用できれば, 効率の良い演 算器使用が可能であることが予想される。

このように, 放送映像信号処理を対象としてプログ ラマブルに演算器制御を高速に行い, かつ演算器間接 続を高い自由度で行える信号処理プロセッサシステム は，NTSC 用としては例えばNTSC 版 Picot などが あるが,さらに HDTV 用として高速演算だけでなく 低速信号処理の共用も考慮された信号処理プロセッサ システムは, これまで存在しなかった。そこで, 高速 の演算器間の接続の自由度の高い信号処理プロセッサ を 3 章で仮定し, 考察を進めていく.

\section{DSP モデルの設定}

2 章での考察から, HDTV, NTSCの両方に対応 できる映像信号処理 DSP のモデルを設定するにあた り，下記の条件を考える。

(1) 高速な演算器を複数持つ

近年のデバイス技術の向上にともない, HDTV 信 号対応の高速演算を行う演算器を 1 つの IC 内に複数 個持つことは容易である。ここでは前記のように HDTV 対応の演算速度をサンプリング周波数の半分 の $37.125 \mathrm{MHz}$ に設定する.

当然のことながら, 演算器は多数あれば(例えば, $m$ 個あれば） $m$ 倍の演算が可能である.ただし, 複 数の演算器間の接続が固定なら, ある演算処理はでき ても別な演算処理には適用できず，この 2 種の演算処 理をこなすためには, さらに多数の演算器が必要にな る.したがって, 演算器間の接続を行う部分のオーバ ヘッドが小さければ, 必要な演算器数の比較は以下の ようになる。

ある演算処理 $i$ に対して必要な演算器数を $m_{i}$ とす ると, 全体の演算器数は, 接続が固定なら $\sum m_{i}$ とな り, 接続が可変なら, 最も効率良く演算器を使用した 場合で $\operatorname{Max}\left(m_{i}\right)$ となり, この比が効率向上の指数と なる。

（2）演算器間の接続が任意にしかもクロック単位 に変更できる

テレビジョン学会誌 Vol. 49, No. 4 (1995) 


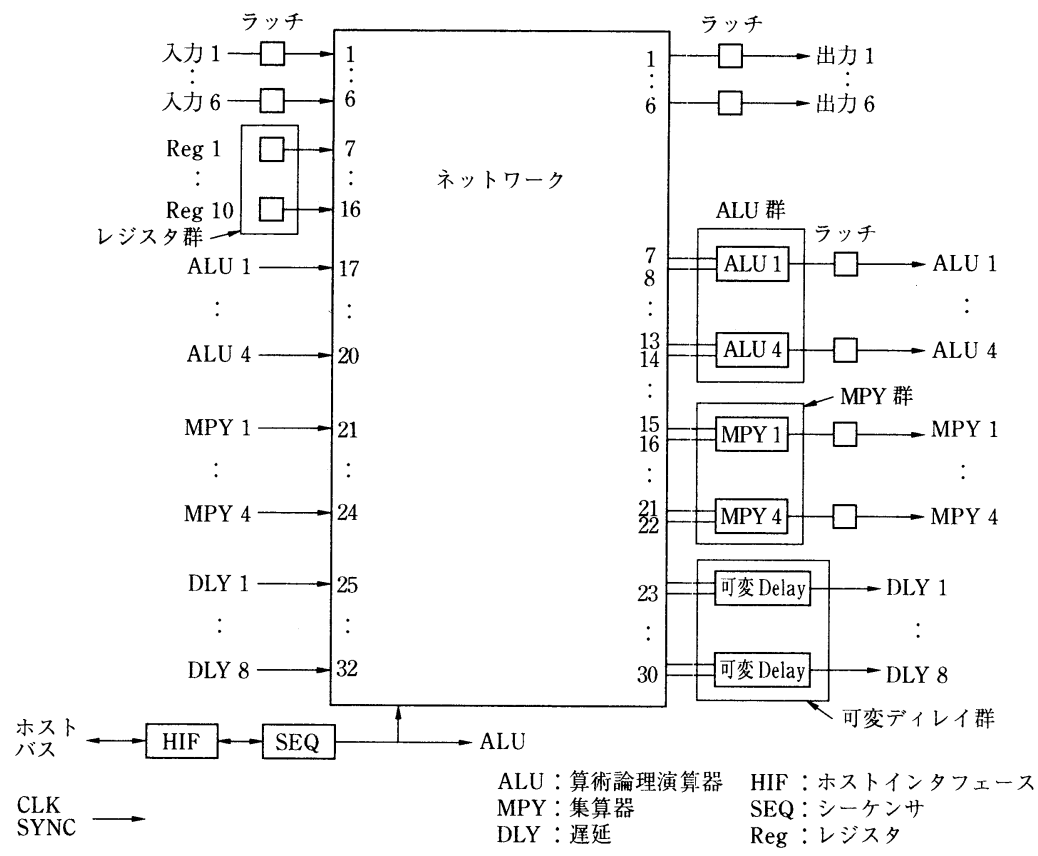

図 1 DSP のモデル

Model of DSP.

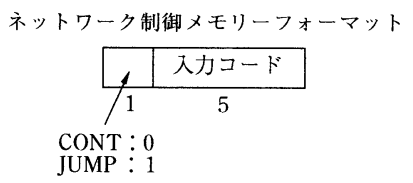

各出力に対するネットワーク制御メモリー

\begin{tabular}{|l|c|}
\hline 0 & 入カコード 1 \\
\hline 0 & 入カコード 2 \\
\hline 1 & 入カコード 3 \\
\hline \multicolumn{2}{c}{ 空 } \\
\hline
\end{tabular}

$\begin{array}{cl}\text { クロックレート } & 0: \times 1 \\ (1 \mathrm{~b}) & 1: \times 1 / 2\end{array}$

入カコード 1, 2, 3 を3 クロックでサイクリックにとる.

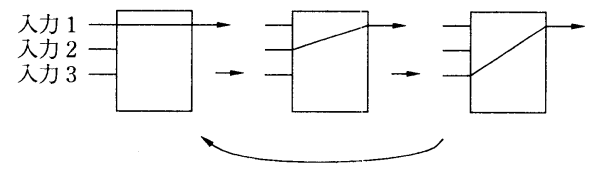

図 2 ネットワーク制御メモリー

Network control memory.

複数の演算器があっても, その接続の自由度がない と有効に利用できない.ここでは演算器間接続が自由 に行える高速のネットワークをIC 内に持つことを考 える. 複数の演算器間の接続が演算速度と同速度でク ロック毎にプログラムで切替可能とする。これにより 単一の演算器を利用して複数のクロックで複数の演算 処理を実行できることになる。

以上のような条件で映像信号処理プロセッサのモデ ルを図 1 のように設定した.アーキテクチャ上の工夫 点としては, 演算器間を自由に接続できるように入出 カをネットワークを介して接続していること踣, 可 ディレイ群を設けていることである.（2）の条件のた
め, ネットワーク制御はプログラムによりクロック単 位で動作し，繰り返し動作を実現するために適当な番 地からプログラムの先頭へループするものとする．す なわち, 図 2 に示すように, 各出力に対し 4 ワードの ネットワーク制御用メモリーを持ち, 各ワードには出 力に対応する入力コードと，下に抜けるか 0 番地へ戻 るかの選択姿行う指示ビットがあるものとする。これ により最大 4 クロックサイクルの処理が可能となる (最大 4 クロックサイクルという值の理由は 4.1 節 (2)参照)。また，2クロック毎にしか $\mathrm{NW}$ 制御の必 要のない場合もあり, その場合はクロックレートを $1 / 2$ に指定することにより 2 クロック毎に 4 回の制御 
表 2 DSP の概要

Summary of DSP.

\begin{tabular}{|c|c|c|}
\hline \multirow{2}{*}{$\begin{array}{l}\text { レジスタ } 1 \sim 10 \\
\text { 入カ } 1 \sim 6 \text {, 出力 } 1 \sim 6\end{array}$} & 16 bレジスタ & 2 バンク \\
\hline & 12 b レジスタ & \\
\hline ALU $1 \sim 4$ & $16 \mathrm{~b}$ & 4 kgate $/ \mathrm{ALU}$ \\
\hline MPY $1 \sim 4$ & $12 \mathrm{~b}$ & 3 kgate/MPY \\
\hline 可変ディレイ 1〜8（最大 4 タップ） & $16 \mathrm{~b}$ & \\
\hline ネットワーク & 32 入力 30 出力 & 12 or $16 b$ \\
\hline ネットワーク制御メモリー & $6 \times 4 \times 30=720 b$ & 2 バンク \\
\hline $\begin{array}{l}\text { ALU 制御メモリー } \\
\text { SEQ, HIF }\end{array}$ & $4 \times 4=16 b$ & 2 バンク \\
\hline \multicolumn{3}{|c|}{ 総ゲート数 約 $100 \mathrm{k}$ ゲート } \\
\hline 総ピン数 209 ピン & \\
\hline 演算速度 & \multicolumn{2}{|c|}{$\begin{array}{l}209 \text { ピン } \\
37.125 \mathrm{MHz} \text { 以上 }\end{array}$} \\
\hline
\end{tabular}

が行えるようにしておく、ネットワークの制御は垂直 ブランキング期間 $(\mathrm{VBL})$ から映像有効期間になった タイミングで制御を開始するものとする。このような 演算器間をネットワークで接続するという発想は, 筆 者らの提案した「Picot システム」 ${ }^{2)}$ で出てきたもので あり，本論文ではさらにそれを発展させ，クロック毎 に接続を切換えて演算器の効力利用を図ることを考え た.

このような信号処理プロセッサのモデルをハードウ エア化した場合の概要を表 2 に記す。この ICをゲー トアレイで実現したとしても, ゲート数，スピードと も，充分現実的な值である。

\section{4. 低速信号処理時の多重使用}

ここでは，HDTV，NTSCのそれぞれについて信 号伝送形式と，それにともない想定した信号処理プロ セッサの使用形態を検討し, 高速演算器の低速信号処 理時の有効利用について考察する。 まず，用語の定義 について述べる。

\section{1 用語定義}

（1）高速/低速

高速信号は HDTV レベルの速度を意味し，低速信 号はNTSCレベルを意味する。高速演算器とは HDTV 信号を処理できる速度の乗算器または算術論 理演算器 (以下 ALU) を意味する。実際は通常使われ るCMOS ベースの ASICで実現可能なデバイスの演 算速度 (クロック周波数) として, HDTV 信号の標本 化周波数 $74.25 \mathrm{MHz}$ の $1 / 2$ の $37.125 \mathrm{MHz}$ が想定さ れる。

（2）多重度 $m$, 伝送レート $r_{1}$, サンプリングレ 一ト $r_{2}$

伝送レート $r_{1} を$, 映像信号の伝送クロックレート
であり，信号処理プロセッサのクロックレートであ り，高速演算レートにもなる值とする。また処理され る映像信号のサンプリングレートを $r_{2}$ とした時, 多 重度 $m$ は (1)式で与えられる。

$$
m=\frac{r_{1}}{r_{2}}
$$

通常 NTSC 信号への適用を考えた場合，モデルに 設定した DSP の速度からサンプリングレートの 2 倍 まで伝送レートを上げられるので， $r_{1}=14.3, r_{2}=28.6$, $m=2$ となる。また C 信号は $\mathrm{Y}$ 信号の $1 / 2$ の帯域な ので $\mathrm{Y}$ 信号に対し $m=2$ であれば $\mathrm{C}$ 信号については $m=4$ となる。そこで本論文では $m=4$ をMax とし て想定している。

\section{(3) 演算器数 $n$}

乗算器 (MPY) とALU の数は必ずしも同数にする 必要はないが, ここでは MPY $n$ 個, ALU $n$ 個が 1 つの信号処理プロセッサ内に装備されているものと し, 演算器数 $n$ と定義する.

(4) ステージ

多重度 $m$ の場合， 1 サンプル期間は $m$ 個のクロッ クから構成されるので, その $m$ 個のクロックに順番 をつけて, $i$ 番目 $(1<i \leqq m)$ のタイムスットを第 $i$ ステージと呼ぶことにする。

\section{2 映像信号の伝送形式と演算器の使用形態}

本節では, HDTV, NTSC 信号の各種伝送形式と 演算器の使用形態について説明する.

\section{(1) HDTV}

HDTV 信号の伝送形式は, 標本化周波数 74.25 $\mathrm{MHz}$ で伝送周波数を $37.125 \mathrm{MHz}$ とすると下記の形 態になる。

$\begin{array}{lll} & \mathrm{Y}_{\mathrm{e} 1}, \mathrm{Y}_{\mathrm{e} 2}, \mathrm{Y}_{\mathrm{e} 3} \sim & \mathrm{e} \text { は偶数番目, } \\ \text { 並列 } & \mathrm{Y}_{\mathrm{o} 1}, \mathrm{Y}_{\mathrm{o} 2}, \mathrm{Y}_{\mathrm{o} 3} \sim & \mathrm{o} \text { は奇数番目の } \\ \text { 伝送 } & \mathrm{P}_{\mathrm{r} 1}, \mathrm{P}_{\mathrm{r} 2}, \mathrm{P}_{\mathrm{r} 3} \sim & \text { 画素を表す. } \\ & \mathrm{P}_{\mathrm{b} 1}, \mathrm{P}_{\mathrm{b} 2}, \mathrm{P}_{\mathrm{b} 3} \sim & \end{array}$

輝度信号( $\mathrm{Y}$ 信号) は $74.25 \mathrm{MHz} レ$ レを 37.125 $\mathrm{MHz} 2$ 本で並列伝送し, 色信号 $\left(\mathrm{P}_{\mathrm{r}}, \mathrm{P}_{\mathrm{b}}\right.$ 信号) は輝度 信号の $1 / 2$ の帯域なので $37.125 \mathrm{MHz} 1$ 本で伝送す る。

（2）NTSC-2(コンポジット)

伝送レートを映像サンプリングレートの整数倍(下 記の例では $m$ 倍)にする。この場合，コンポジット信 号を $V_{i}(i=1,2, \cdots)$ とすると下記の形式となる.

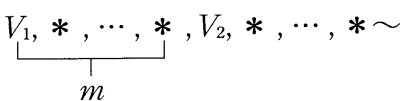

*はダミーデータである. $m$ が整数であるので $(m$ 
-1) 個のダミーデー夕を挿入するのみで, 特に速度 変換のためのメモリーは必要としない。この場合, 可 変ディレイのダイナミックな接続により演算器使用効 率の向上が期待できる。これについては 4.3 節で詳細 検討を行う。

（3） NTSC-3(コンポジット)

伝送レートをサンプリングレートの整数倍とした 時, 複数のコンポジット信号を位相をずらして時分割 多重する. $m=2$ の場合, 2 つのコンポジット信号を $V_{a i}, V_{b i}(i=1,2, \cdots)$ とすると下記の形態になる.

$V_{a 1}, V_{b 1}, V_{a 2}, V_{b 2} \cdots$

( 2 ) は ( 3 )の特殊ケースであり, 同様な演算器使用 効率の向上が期待できるが, 本論文では検討は行わな い.

（4） NTSC-4(コンポーネント)

コンポーネント信号の伝送形態は, サンプリング周 波数 $13.5 \mathrm{MHz}$ の 2 倍の $27 \mathrm{MHz}$ のレートで $\mathrm{Y}$ 信号 と C 信号が時分割多重されて伝送される.

$\mathrm{Y}_{1}, \mathrm{C}_{\mathrm{R} 1}, \mathrm{Y}_{2}, \mathrm{C}_{\mathrm{B} 1}, \mathrm{Y}_{3}, \mathrm{C}_{\mathrm{R} 3}, \mathrm{Y}_{4}, \mathrm{C}_{\mathrm{B} 3}, \sim$

（３）と異なるのは異種の複数信号のインタリーブで ある点であるが，（3)の特殊なケースと考えることも でき，本論文では検討は省略する．

\section{3 多重使用}

まず 4.2 節 $(2)$ のケースに扔いて, 可変ディレイの ダイナミックな接続により同一演算器を多重使用して 使用効率を上げる方法について考える。前記のように 多重度 $m$ の場合, 入力デー夕は $m$ 個に 1 個のみ有効 で, 残りの $(m-1)$ 個はダミーデータである.

(1) ケーススタディ

・ケース 1 ここでは演算器数が 1 ～2 少ない

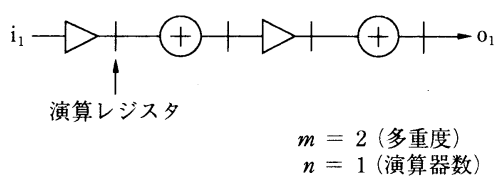

(a)

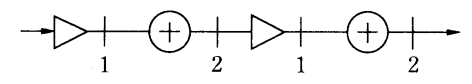

(b)

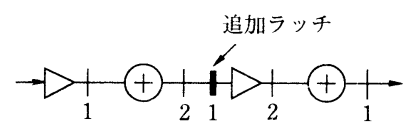

(c)

$\longrightarrow$ : MPY

図 3 ケース 1

Example 1.

ケースについてまず検討を行う。また MPY, ALU の演算器は本来 2 入力だが, 簡単のため定数との演算 の場合は 1 入力のような書き方をする例もある。まず 図3(a)のケースを考える (演算結果をラッチして格 納する演算レジスタが|で表示され, 後述の追加ラッ チは太線の】で表示されている)。演算は 2 ステージ/ デー夕をとることができるので，ステージをそのまま 割り振ると図 $3(\mathrm{~b})$ となり, MPY, ALU とも第 1 , 第 2 ステージへのふり分けができない(演算レジスタ の記号の所にステージNo を記入してある. MPY は 2 個とも第 1 ステージ, ALUは 2 個とも第 2 ステー ジになる。もし ALU, MPYを, 1 デー夕内で第 1 , 第 2 ステージと割り振れれば，異る種類の計算を単一 の演算器でできることになる)，そこで一般的にディ ジタル信号処理回路では, 複数信号間, あるいは基準 信号に対する位相合せのためシフトレジスタが使用さ れること考慮し，一段のシフトレジスタであるラッ チを 1 つ追加してみると図 $3(\mathrm{c})$ のようになる。これ により MPY, ALUの第 1, 第 2 ステージへの振り 分けが可能になり，1つの物理的な演算器がブロック 図上の 2 つの演算を果たすことになり, 演算器を有効 に使用できる. 各ステージにおける演算器間の接続を 図 4 亿示守.

・ケース 2 MPY, ALUが 2 個ずつで多重度 は 2 とすると, 4 回ずつ乗算, 加算ができるという例 である。この場合, どの演算を 1 つの演算器に多重す るかにより，いくつかの振り分けがあり, 図5の(b) と (c) に線で囲んで示してある.ここで図 5(c)の一 部を取りあげると, $m=2, n=1$ として図 6 のように 追加ラッチが必要となる. 追加ラッチ 1 は MPY のス テージ振り分けのためラッチであるが, 追加ラッチ 2 は $i_{1} \rightarrow \mathrm{ALU}$ と $i_{2} \rightarrow \mathrm{ALU}$ の経路長(ラッチ数)が変わ らないように入れたものであり, 追加ラッチ 1 に対す る付随的なものであり,このような経路長合わせが必 要になることがわかる。

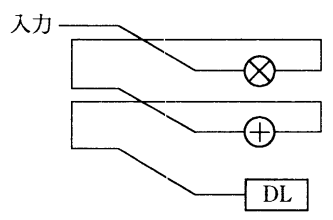

第 1 ステージ (人力データ有効, 出力デー夕無効)

図 4 演算器間接続例

Example of the connection between the multiplier and ALU.

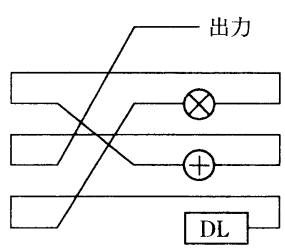

第 2 ステージ

(入力データダミー， 出力デー夕有効) 


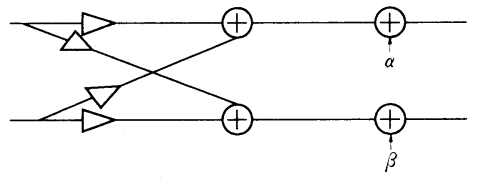

(a)

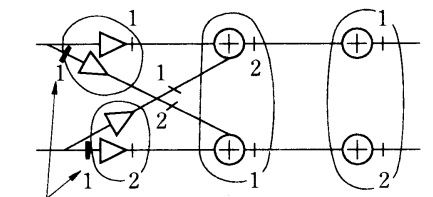

(b)

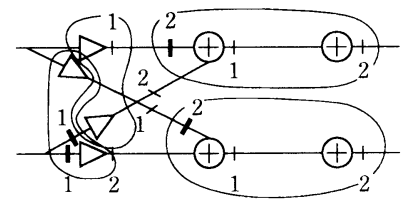

(c)

図 5 ケース 2

Example 2.

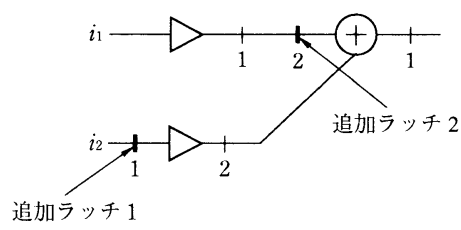

図 6 ケース 2 の一部

Part of example 2.
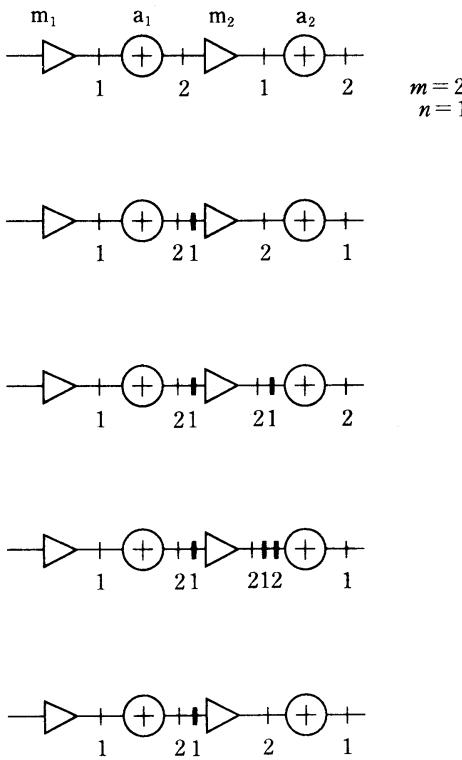
ふり分ける。

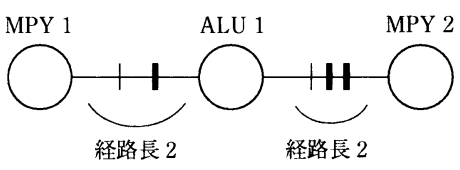

(a)

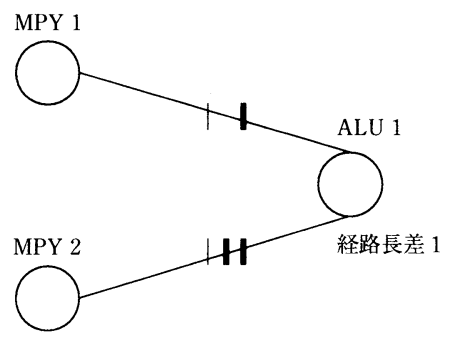

(b)

図 7 経路長の説明

Explanation of path length.

（2）アルゴリズム

本節では, フィードバックループを除く回路網につ いて, 高速演算器を多重使用する場合の可変ディレイ 挿入アルゴリズムについて考察する．今，フィードバ ックループを除いた有向グラフ $\mathrm{G}_{\mathrm{p}}$ において, 演算器 $m_{i}$ と $m_{j}$ を異なるステージに振り分けたい場合で, かつ $m_{i}$ と $m_{j}$ が同一ステージにある場合, $m_{i}, m_{j}$ の いずれかの手前にラッチを 1 つ挿入することでステー ジ振り分けを 1 段階進めることができる。この際，そ れまでに完成しているステージ振り分けに影響を与え

初期状態，2 個の MPY，ALU は同一ステージ

になっている。 $\left(\mathrm{m}_{1}\right.$ と $\mathrm{m}_{2}$ は第1ステージ， $\mathrm{a}_{1}$ と $\mathrm{a}_{2}$ は第 2 ステージ)

まず，MPYを 1,2 ステージへふり分

ける。（本当はこれでできている)

$\operatorname{ALU~}\left(\mathrm{a}_{2}\right)$ を前の状態に戻す

次にALUを $1 ， 2$ ステージへ

$\mathrm{ALU}_{2}$ の前のラッチが 2 個まとまったので除く. (経路長合わせに無関係なので)

図 8 ケース 1 再考

Re-study of example 1 . 
なければ, 有向グラフ $\mathrm{G}_{\mathrm{p}}$ においてラッチの数はシス テムディレイに関係するのみなので，いつかは必ず完 成することになる。これまでに完成しているステージ 振り分けに影響を与えないためには，ラッチを挿入し た演算器の直後に(ステージ数ー1) 個のラッチを挿入 した後, 経路長合せを行えばよい. 最後に 1 つの技の $m$ 個の連続したラッチは経路長差が保たれるように 注意して取り除く．振り分けるステージ数は，入れる ラッチの数により決まるので, 任意のステージへ振り 分けることが可能となる。ここで経路長とは演算器を ノードとするネットワーク経路におけるラッチの総数 であり，経路長合せとは 1 つのノードに入る経路長の 差を一定とすることである (図 7 参照)。以下，図 8, 図 9 の例によりアルゴリズムを実証していく

図 8 においてはまず $m_{2}$ のステージ振り分けのた

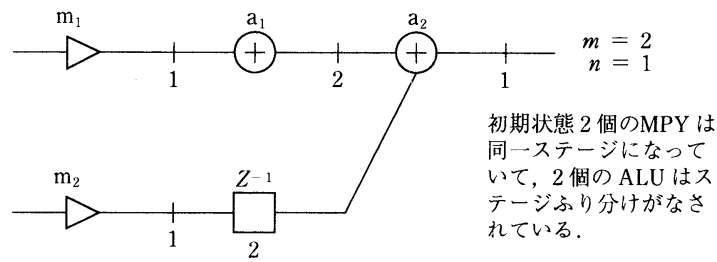

(a)
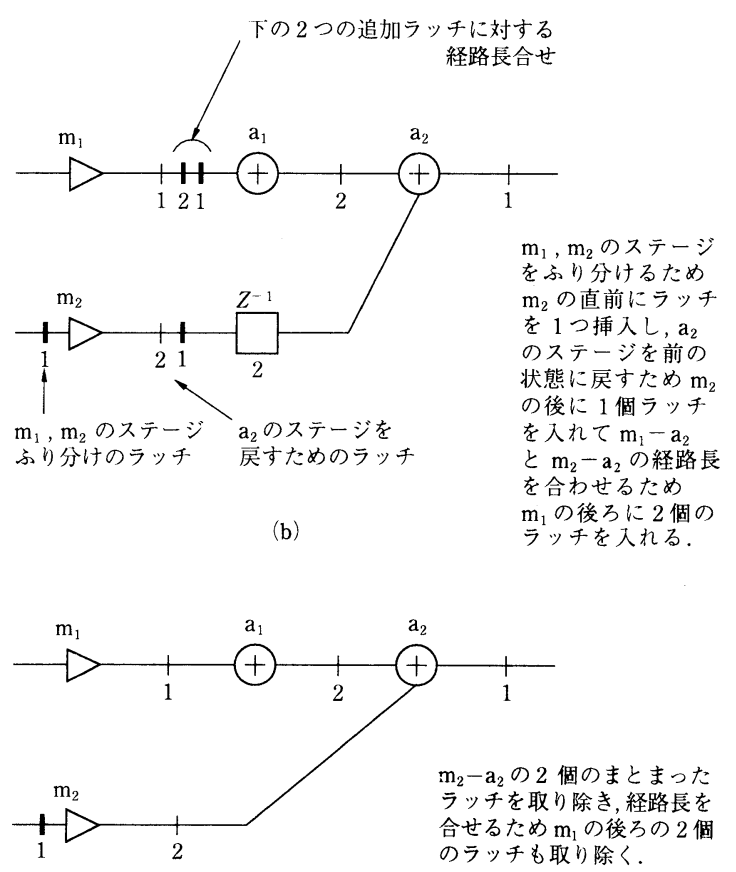

(c)

図 9 ケース 3

Example 3.
め, $a_{1}$ と $m_{2}$ の間に追加ラッチを入れ， $a_{2}$ を元の状 態に戻すため $m_{2}$ と $a_{2}$ の間と追加ラッチを入れ，さ らに $a_{2}$ のステージ振り分けのため, $m_{2}$ と $a_{2}$ の間に 追加ラッチを入れた後, $m_{2}$ と $a_{2}$ の間のラッチをまと めて 2 個除いている. 図 9 においては, さらに $2 つ の$ パスの経路長合せの追加ラッチが $m_{1}$ と $a_{1}$ の間に必 要である.

これらの例から，フィードバックを含まない回路網 について, 前記アルゴリズムに従って演算器のステー ジふり分けによる多重使用が可能であることがわかっ た．フィードバックを含む場合は，当然ループ内のラ ッチの数を変えることはできず，上記アルゴリズムは 適用できないが，映像信号処理においてはフィードバ ック回路網の利用例は少いので問題はない ${ }^{334)}$. 可変 ディレイのダイナミックな接続により演算器を多重使 用する本方式については，PC 上で機能シミュレーシ ヨンにより動作を確認している。

\section{5. スタジオ機器への応用5)6}

ここでは，4 章で考察した各種の使用形態の複合応 用例として, 実際のスタジオ機器で使用されている各 回路についてこの構造を明らかにし, 本論文で提案し ている信号処理プロセッサ(以下，DSP)のアーキテ クチャの適用を考察した。アプリケーションとして NTSCのディジタルマスターを取りあげ，映像処理 部ブロック図を図10 亿示す。標本化周波数 14.3 $\mathrm{MHz}$ のコンポジットディジタル信号であり, 量子化 10 ビットである。機能としてはFA (Fading Amp) 部, プロセス部, スーパー部(原色スーパー含, 2 系 列)功構成される。次に補足説明する。

\section{(1) FA 部}

((BASE 列の映像信号レベル) -240$) \times K$

$10 \mathrm{~b}$ 量子化で 240 となるペデスタイルレベルを引 く.フェードイン, フェードアウト処理も行う.

(2) プロセス部

hue, sat, ped, gain $(\gamma)$ のプロセスを行う.

(3) $\mathrm{OL}$ 部 $\mathrm{Y} / \mathrm{C}$ sep

色付きスーパー素材対応の処理を行う.

(4) Letter Key 発生処理

通常はＹ信号で良いが，Y が低くて sat が高い場 合の Letter Key 発生のための処理を行う.

$$
a \times|c|+b, \quad a, b: \text { パラメータ, } c: \mathrm{I}, \mathrm{Q}
$$

全体としてュニット 6 枚 $(\mathrm{FA}+$ プロセス 1 , NAM 1，スーパー4)構成が現状である.

次に, 本論文で提案しているDSP のICのディジ タルマスターへの適用を考えてみる。図 10 を演算器 


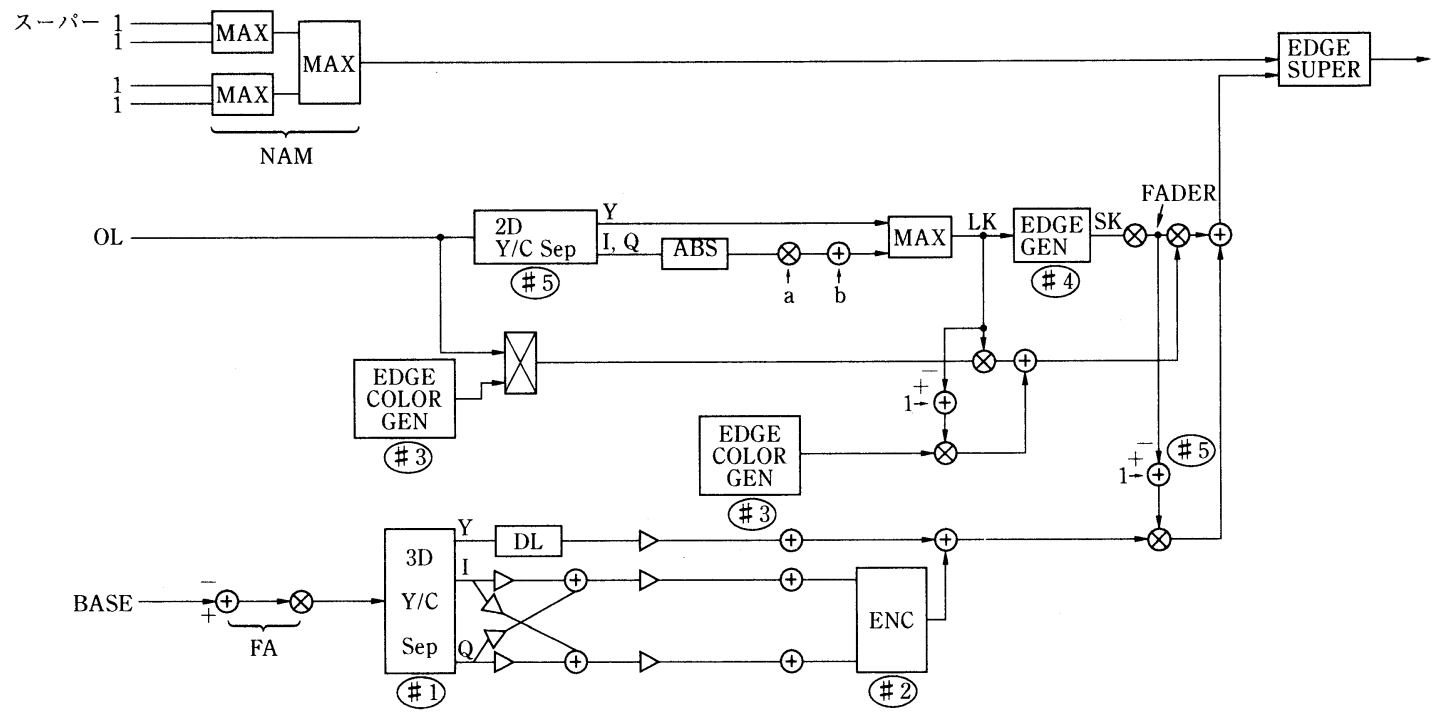

図 10 NTSC ディジタルマスター映像処理部ブロック図

Block diagram of the NTSC digital master control system.

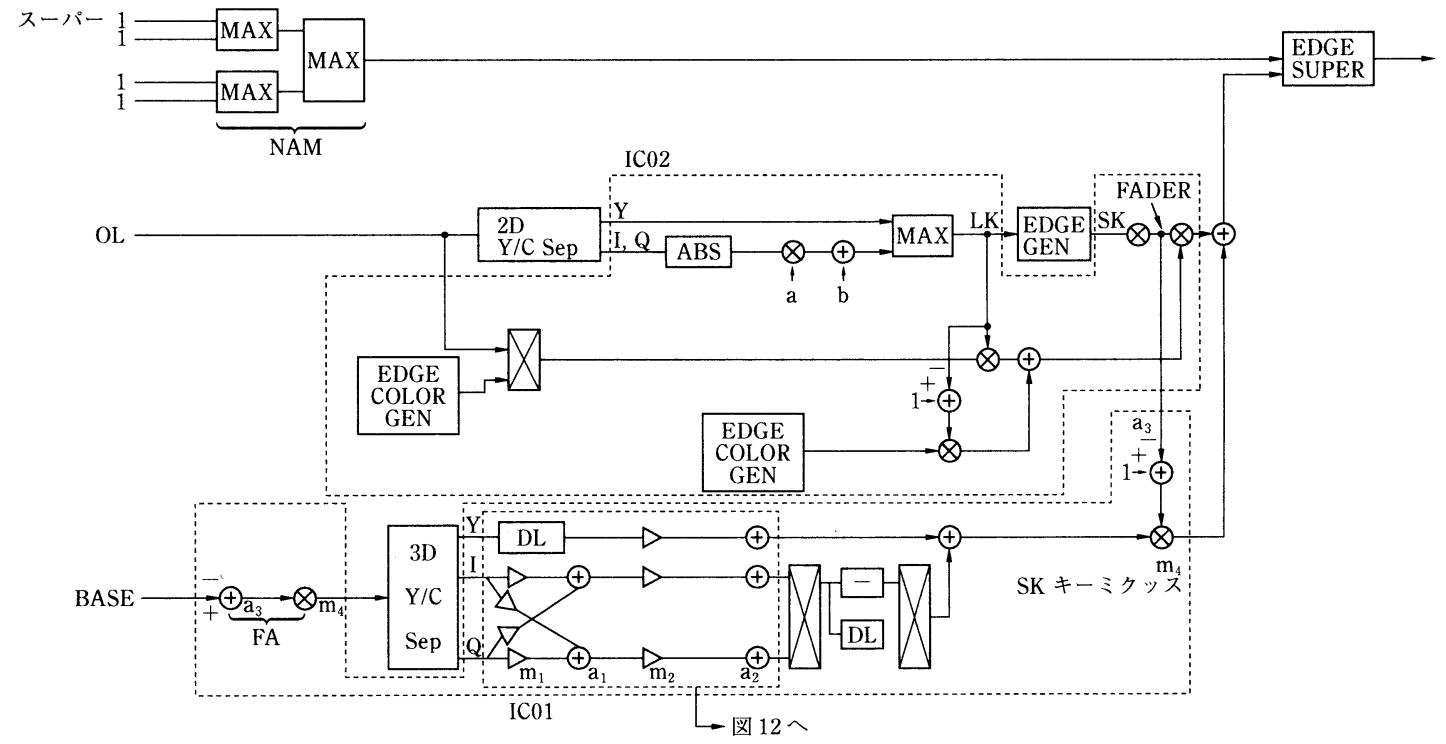

図 11 ディジタルマスター演算 IC 割当

Assignment of DSPs for the digital master control system.

レベルまで落とし, さらに DSP の IC 内の各演算器 に振り分けてみると図 11 の点線のようになる。演算 器の有効利用という面から,できるだけ演算器を使い 切るようにしてみた。

次に IC 01 に振り分けられた各回路についてみてい く.図11の一部である図12(a)については, I, Q は $1 / 4$ レートなので 1 個の MPYを 4 回切換えて使 う. ALUは $1 / 4$ レートで 2 回使うので半分しか使用 していない. 図12(b)については, Y は $1 / 2$ レート,

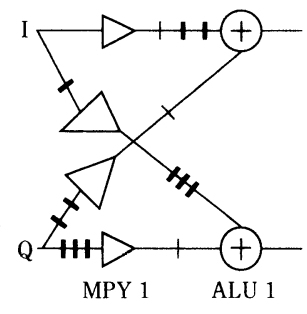

(a)

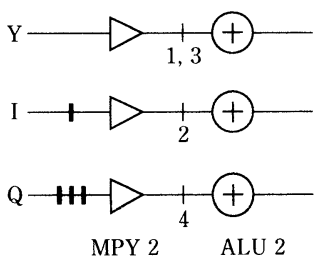

(b)

図 12 図 11 の回路の一部

Part of the circuit diagram of Fig.11.

テレビション学会誌 Vol. 49, No. 4 (1995) 
I，Q は $1 / 4$ レートなので MPY, ALU 各 1 個ですべ てをまかなえる(Y, I, Y, Q と切換えて計算する)。 IC 01 についての演算器の使用率は下記のようになる.

$\begin{array}{rrrr}\text { MPY 1 } & 1.0 & \text { ALU 1 } & 0.5 \\ 2 & 1.0 & 2 & 1.0 \\ 3 & 0.5 & 3 & 1.0 \\ 4 & 1.0 & 4 & 0.5\end{array}$

演算器使用率 $81 \%$

また, 図 12 (a)でI, Q の信号処理に 4 個の MPY と 2 個の ALU が必要であったのが, 図 12 (b)のI, Q では MPY と ALUが 2 個ずつであり， 3 章で述べ た効率向上の指数は 1.5 となる.

これから, 全体でDSPのIC 3 個と, $3 \mathrm{D} \mathrm{Y} / \mathrm{C}$ sep 部, EDGE 発生用フィルタ部 $\times 2$ で構成できるこ とになる。従来はディスクリート回路で組まれていた ので, DSP 化による効果と演算器の多重使用による 使用率向上による効果により，ユニット枚数を現状の システムの半分にすることができる．DSP 内の演算 器接続は完全にプログラマブルなため, 柔軟に系統追 加などの回路変更に対応できる.

\section{6. む す び}

以上述べてきたように，ハイビジョンを対象とす る, 高速演算素子の低速信号処理時の多重使用による 効率向上について, 信号処理プロセッサの IC のモデ リングを行い, 種々の使用形態を考え, 各方式につい て具体的なケーススタディをふまえながら効率の高い
使用法とそのアルゴリズムを示した。また放送局内の アプリケーションとして, マスター送出設備等への適 用例を考察し，スペースファクタ向上に関して相当の 効果があることが確認できた。近い将来のデバイス技 術向上を考えると，ネットワーク部のシリアル化はか なり実現性も高く, その場合, ゲート規模でのネット ワーク部のオーバヘッドは現在の想定以上に小さくな り，ますます有効性は向上するものと思われる．

今後は, 信号処理プロセッサの IC の実現や，演算 素子の自動ふり分けソフトウェア開発等が課題となる と思われる。

本研究に当たり, 有益なご助言を頂いた NHK 放 送技術研究所, (株) 東芝小向工場の関係各位の方々に 感謝いたします。

\section{〔参 考 文 献]}

1）榎並, 八木, 矢島, 福井, 金井, 三上, 村上, 佐々木, 星野, 春川, 小暮：“沉用映像信号処理システム-Picot システム”, テレビ 誌, 43, 2, pp. 178-186(1989)

2）八木, 矢島, 榎並, 三上, 佐々木, 星野, 春川, 山田 : “実時間映 像信号処理 LSI-Picotのアーキテクチャ”, 信学論 C-2, J72C, 5, pp. 346-353(1989)

3）八木：“リアルタイム映像信号処理装置とその応用”, 情処学 誌, 34, 11(1993)

4）日本放送協会編：“放送におけるディジタル技術”, pp. 178181, 日本放送出版協会

5）高橋, 萬：“NHK 放送センターディジタル切り換え・分配 システム”, テレビ学技報, 15, 8, pp.7-12, BFO 91-2（Jan. 1991)

6）“最新の放送技術”，テレビ誌，46,4（1992）

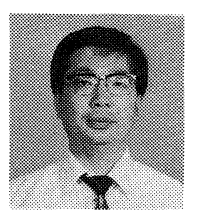

佐々苔信之昭和 51 年, 東京大学大学院 電気工学尃攻修士課程修了。同年, (株) 東芝 に入社. 放送局向けスタジオ機器の開発・設 計に従事. 工学博士. 正会員.

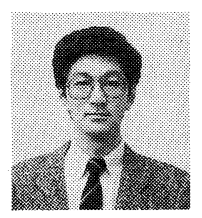

八柋伸行 昭和 55 年, 京都大学大学院 電気工学専攻修士課程修了. 同年, NHK 入局. 昭和 57 年より, 同放送技術研究所に 勤務。現在, 同所先端制作技術研究部に所 属. 画像処理システム, 動画像処理, 番組制 作技術の研究に従事. 工学博士. 正会員.

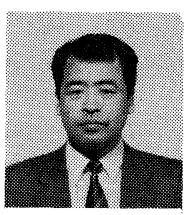

福并架 拭势 昭和 50 年, 東京工業大学大 学院電子物理工学専攻修士課程修了. 同年, NHK に入局. 甲府放送局を経て, 昭和 54 年より, 放送技術研究所に勤務. コンピュー タグラフィックス, 画像処理装置等の番組制 作のための映像機器の研究, 開発に従事. 現 在, 同所先端制作技術研究部主任研究員. 正 会員.

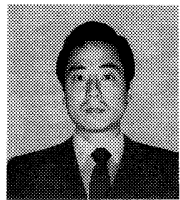

㒭なみ がきき

榎並 和雅 昭和 46 年, 東京工業大学電 子物理工学科卒業. 同年, NHK に入局. 金 沢放送局を経て, 現在, 同放送技術研究所先 端制作技術研究部部長. ディジタル映像処理 技術, 並列コンピュータアーキテクチャの研 究注従事. 工学博士. 正会員. 